\section{Bipolar lidelse - den nye epidemien}

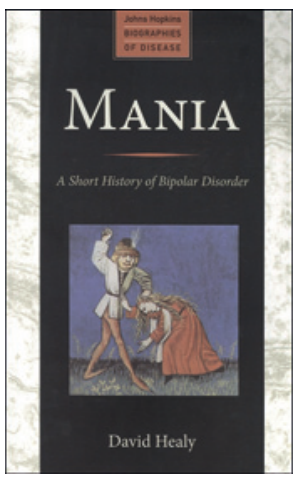

David Healy

\section{Mania}

A short history of bipolar disorder. $296 \mathrm{~s}$ Baltimore, MD: The Johns Hopkins University

Press, 2011. Pris USD 25

ISBN 978-1-4214-0397-7
I 1980-årene så man i USA nærmest en epidemi av multippel personlighetsforstyrrelse i kjølvannet av de mange rettssakene etter seksuelle overgrep. Epidemien døde ut i 1990-årene etter avsløringer av flere terapeutiske skandaler som var knyttet til denne diagnosen. Men nye amerikanske psykiatriske epidemier har siden sett dagens lys, som Aspergers syndrom, $\mathrm{AD} / \mathrm{HD}$ og nå bipolar lidelse. $\mathrm{Ja}$, til og med barn får nå denne diagnosen i USA, og det rapporteres om medikamentell behandling for bipolar lidelse helt ned til toårsalderen.

Den britiske psykiateren og psykofarmakologen David Healy publiserte i 1997 The antidepressant era, der han gir en glimrende fremstilling av 1990- årenes «depressive epoke», hvor salget av de nye antidepressivene nådde svimlende høyder i vestlige land.

I sin nye bok, med den litt misvisende hovedtittelen Mania, gir Healy en inngående skildring av utviklingen av diagnosen maniskdepressiv sinnslidelse.

\section{Historien}

Begreper som mani, melankoli, galskap, dysfori, dystymi og paranoia går tilbake til de gamle grekerne og romerne, men maniskdepressiv sykdom er et nyere begrep som vanligvis knyttes til Emil Kraepelins (1856-1926) inndelinger fra slutten av 1890-årene. Healy viser imidlertid at sjefen for McLean-hospitalet i Boston, Rufus Wyman (1778-1842), allerede i 1830 beskrev sykdommen. I 1899-utgaven av sin lærebok inkluderte Emil Kraepelin symptombilder som hebefreni, katatoni og paranoid psykose i sitt begrep dementia praecox. Manisk-depressiv psykose ble omtalt nærmest som en kontrast til dementia praecox. Det nye ved Kraepelins inndeling var den vekt han la på prognosen. Mens dementia praecox (schizofreni) $\mathrm{i}$ alminnelighet hadde en dårlig prognose, hadde manisk-depressiv psykose en god prognose.

I 1966 publiserte både Jules Angst (f. 1926) i Zürich og Carlo Perris (1928-2000) i Umeå arbeider som skilte ut bipolar lidelse med både depresjon og mani fra unipolare depresjoner, tidligere ofte benevnt endogene depresjoner. Disse ville være forskjellige både hva angår forekomst og genetikk. Senere har man fått en inndeling av bipolar lidelse i bipolar I med alvorlig mani og depresjon og bipolar II med lettere mani og depresjon. Problemet var imidlertid hvordan man skulle kunne skille mellom bipolar depresjon og unipolar depresjon i de tilfellene hvor den såkalte bipolare depresjonen ikke hadde vist noen manisk fase.
Healy skriver også om litiumstriden mellom dansk og britisk psykiatri der Mogens Schou (1918-2005), med basis i en rekke danske undersøkelser, hevdet at litium hadde forebyggende virkning ved manisk-depressiv sinnslidelse, mens Michael Shepherd (1923-95) ved Maudsley-hospitalet i London gjennom alle år hevdet at den preventive virkningen til litium var en myte. De danske undersøkelsene var uten placebo som kontroll. Interessant er også Healys beretning om hvordan medisinalindustrien klarte å få fjernet litium i den forebyggende behandlingen til fordel for antiepileptiske midler, som angivelig skulle ha en «stemningsstabiliserende» virkning.

\section{De seneste årene}

Kanskje det mest skremmende i dagens situasjon er bruken av diagnosen bipolar lidelse på urolige barn. Mellom 1996 og 2001 var det i USA en femdobling av medikamenter som Zyprexa og Risperdal (antipsykotiske midler) gitt til barn under 13 år, og mellom 1996 og 2004 var det en femdobling av innleggelser av barn med diagnosen bipolar lidelse. Flere studier viste at hos barn ble denne diagnosen stilt poliklinisk 40 ganger oftere enn for et tiår siden.

Årsakene til denne utviklingen er nok mangesidig. En del klinikere ønsker åpenbart, som shoppere, noe nytt, og på Internett er det mange som finner symptomer som passer med denne lidelsen. Det arrangeres flere og flere konferanser om denne sykdommen, og den farmasøytiske industrien følger opp med støtte til foredragsholdere og reise og hotellopphold for deltakere. Industrien ser selvsagt muligheter for økt profitt.

Det man kan undre seg over, er hvorfor europeiske psykiatere ikke gjør opprør mot den amerikanske psykiatriske dominansen. Amerikansk psykiatri er i dag i krise, og det er lite europeere kan lære av amerikanske kolleger. Amerikanske psykiatere savner åpenbart historisk psykiatrisk kunnskap, og mange har fulgt den ensidige biologiske tendensen med forkjærlighet for klassifikasjon og medikamentell behandling. Man har sluttet å snakke med pasienter. Den kliniske innsikten blir dermed deretter.

\section{Einar Kringlen}

Psykiatrisk institutt, Vinderen

Universitetet i Oslo 